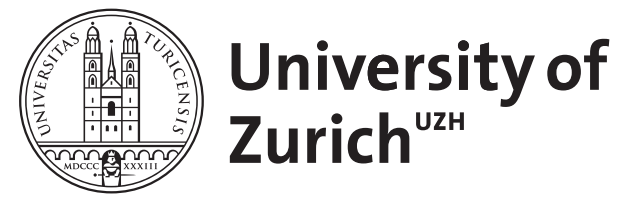
Archive

University of Zurich

University Library

Strickhofstrasse 39

CH-8057 Zurich

www.zora.uzh.ch

Year: 1991

\title{
Religion for the Young in Bible Story Collections (Kinderbibeln)
}

Bottigheimer, Ruth B

DOI: https://doi.org/10.1515/fabl.1991.32.1-2-3.19

Posted at the Zurich Open Repository and Archive, University of Zurich

ZORA URL: https://doi.org/10.5167/uzh-154620

Journal Article

Published Version

Originally published at:

Bottigheimer, Ruth B (1991). Religion for the Young in Bible Story Collections (Kinderbibeln). Fabula, 32(1-2-3):19-32.

DOI: https://doi.org/10.1515/fabl.1991.32.1-2-3.19 
Ruth B. Bottigheimer, Stony Brook, N.Y.

\section{Religion for the Young in Bible Story Collections (Kinderbibeln)*}

\section{Children's Bibles as a Subgenre}

Children's Bibles are a central component of children's religious literature, a genre that also includes Bible excerpts, catechisms, prayers, and morally and religiously edifying literature, both fictional and nonfictional. The boundaries between these subgenres are highly fluid, so that any individual publication may consist of bits and pieces of several of them linked together. In its 'pure' form, each has a specific purpose. Whereas catechisms, for example, ground defined religious principles in individual children or adults, children's Bibles purport to acquaint their young readers with the canonical Bible. More importantly, however, they manifest a socializing intent specific to their readership ${ }^{1}$.

As a genre, children's Bibles exemplify powerfully and peculiarly purposeful storytelling by parents, teachers, and preachers over a five hundred year period. The material that constitutes children's Bibles impinges upon many sociocultural categories, as well as on numerous aspects of the study of folk narrative itself, such as the forms and social functions of folk narrative, storytelling, the aesthetics and poetics of folk narrative, erotic folklore, and folk narrative in education.

Children's Bibles differ from the canonical Bible in several ways. In size they are generally much smaller ${ }^{2}$. The choice of texts is limited, and is, moreover, dictated by sensibilities about what is appropriate for children, sentiments which vary markedly with country, confession, century and class. In literary terms texts generally appear in simplified form, both in vocabulary and in content. The format is frequently catechetical, with specific questions and specified answers. And finally, their place of use is not in the church, but in the home or the school.

* Earlier, and partial, versions of this article were delivered as papers or lectures at the University of Zürich, the University of California, Santa Barbara, the State University of New York at Stony Brook, and at the ISFNR Congress, Budapest 1989.

1 Bible story collections also existed for adults, but since I am particularly interested in the connection between values considered important for socializing the young and the cultural context in which they occur, I have included in my study only Bible story collections unambiguously intended for children as indicated by title page, foreword, or catechetical format.

2 Each of these descriptive parameters is subject to some elaboration. In terms of size, for example, thumb Bibles, which by definition are two centimeters or less in height, are always smaller than the usual Bible story collections. 
Bibles designed and composed particularly for children's use date from the High Middle Ages when Petrus Comestor's Latin school text circulated throughout Europe. His is a well-documented but not much-discussed text ${ }^{3}$. However, the Bible which initiated the Protestant tradition of children's Bibles has lain unnoticed for centuries. This is all the more surprising, because it was composed by Martin Luther himself. First published in 1529, it was widely distributed within Germany ${ }^{4}$, was soon translated into other languages ${ }^{5}$, and was a springboard for generations of illustrated children's Bibles. The tradition of publishing collections of Bible story collections for children continues unabated to this day, extending beyond the Christian West into sub-Saharan black Africa, into Muslim countries, and into shamanistic cultures all over the world 6 .

A final category, about which we remain largely ignorant, is the manner in which Bible stories were actually presented to individual children. Underlying my treatment of the subject of children's Bibles is the conviction that the children's Bible each child holds in its small hand is, for that child, the Bible, that is, not a book like other books, but a sacred text. It is a volume that parents have in all likelihood warned a child not to drop, play with, tear, or get dirty. If the same child reads its collection of Bible stories in school, then the stories are validated not only by the weight of cultural tradition, but also by the authority which schools and teachers also confer and are thus doubly true for the child-reader. In many American children's Bibles of the nineteenth century, the Bible itself is made the subject of illustrations, shown as something supernatural or supranatural on the frontispiece ${ }^{7}$, a representation that both guarantees the text and thematizes its sacral nature.

Each of these components of a children's Bible and of the child's experience of it would seem designed to lead the child to unquestioningly accept the text of a children's Bible as that of the canonical Bible. The text in a children's Bible, however, is not, and never has been, the hallowed text of the Holy Scriptures, but is instead a set of narratives formulated by identifiable people for specific purposes.

Children's Bibles are not self-evident in their overall contents, the sequence of their stories, or the exactitude with which they reproduce the canonical text. One expects to find the Creation of the World and the Birth of Christ in every

3 To date the most extensive treatment of Petrus Comestor's "Historia Scholastica" is Vollmer, H.: Eine deutsche Schulbibel. Berlin 1925, xiii-xxxiii.

4 Within the 16th century, Luther's "Passionalbüchlin" was published repeatedly in Wittenberg by Hans Lufft, but also by other publishers in Leipzig, Nürnberg, Augsburg, and Magdeburg (in Low German).

5 See Higman, F.: Le levain de l'Evangile. In: Histoire de l'édition française. ed. H.-J. Martin/R. Chartier. Paris 1982, 304-325, here 320. Its editorial history shows examples in Danish, Low German, and possibly in French in the 16th century.

6 Large collections of special-readership Bibles exist in several locations. I have used those in the collections of Harvard University, Cambridge University, and the Zentralbibliothek, Zürich.

7 One example among many: The Bible recommended to young people [...] revised by the Committee of Publications. Philadelphia: American Sunday School (early 19th century). 
Christian Bible, whether it is the canonical text or a reworking for children. Yet in the most widely used Latin school Bible text of the sixteenth and seventeenth centuries, the Dialogorum Sacrorum of the Calvinist Sébastien Châteillon ${ }^{8}$, neither the Creation nor the Birth of Christ appears, because neither includes a reproducible dialogue?.

The Bible stories of the Old Testament bear a remarkable resemblance to fairy and folk tales, and in a sense, are such both stylistically and in terms of content ${ }^{10}$. Many of Max Lüthi's characterizations of fairy tales, their structure, and their plot development are equally applicable to Biblical narrative material. Rarely does the narrative tell us either what people look like or what they felt about the events they initiated or from which they suffered. Characters like Adam and Eve, Isaac and Abraham, Joseph and Potiphar's wife, David, Bathsheba, or Solomon function as stock figures on whom didactic narratives are mounted. Like fairy tales, the Bible stories themselves are brief, nonlogical, and full of action. One may justifiedly apply to them and their subsequent retellings in children's Bibles the same methodological principles that are useful in elucidating fairy and folk tales.

The study of children's Bibles provides a link to one of the original categories which folklorists addressed and investigated in the nineteenth century: religious beliefs and their transmission. That research, however, generally sought common denominators within the variety and variation of content and genre in order to determine the origins of underlying beliefs. By moving in the opposite direction, that is, beginning with the original text (the canonical Bible) and then searching out patterns of change in the ways in which the Bible's stories have been retold, one can identify and measure everyday beliefs about culturally determined relationships.

\section{Genesis 3 as an Example of Cultural Variability in Children's Bible Stories}

The evidence offered by children's Bibles themselves provides the most persuasive evidence for their use as a source for differences in and shifts within widely held beliefs and attitudes ${ }^{11}$. Within these story collections, the story of the Fall from Grace in Genesis 3 arouses particular interest, because for centuries it has been made to serve as a paradigm for basic relationships within society:

8 Also spelled Castalio, Castalion, Castellio, Castellion, or Castello, Castillon, Chastallion, Chastillion. I adopt the spelling used in the Handbuch zur Kinder- und Jugendliteratur. Vom Beginn des Buchdrucks bis 1570. ed. T. Brüggemann/O. Brunken. Stuttgart 1987, 978.

9 Châteillon, S.: Dialogorum sacrorum ad linguam simul \& mores pueorum formandos, libri quatuor etc. Basel: Johann Oporinus 1547.

10 This point was often made by 19 th and early 20 th century German Biblical scholars. See for example Gunkel, H.: Genesis übersetzt und erklärt. Göttingen 1922.

11 Because it is all too easy to establish variations by choosing egregious examples, I have chosen illustrative quotations principally from children's Bibles which where publishing successes as demonstrated by having been printed several times over many years. I will draw all examples from the opening verses of Genesis 3. 
between God and humanity, woman and man, life and death, knowledge and ignorance, good and evil, innocence and sinfulness ${ }^{12}$. At bottom the tale resists logical interpretation, a fact which offers a point of entry into changing social views. In the process of trying to make sense of the story about what happened in the Garden of Eden, editors who attempt to make the story comprehensible to yet another skeptical child betray unspoken assumptions about a variety of social and moral relationships ${ }^{13}$. Furthermore, the importance accorded this single tale can often be calculated by the amount of space allotted to it. The 1529 Passionalbüchlin by Martin Luther, frequently republished during the sixteenth century, devotes four of its eleven Old Testament leaves to Genesis 1-3, with two leaves given entirely over to Genesis $3^{14}$. Fresh from his own translation of Genesis, Luther produced a marvel of brevity in his child's ${ }^{15}$ version of the Fall from Grace: "Die schlang sprach zum weibe/Mit nichte werdet yhr sterben/sondern Gott weis/Wenn yhr da von esset/so werdet yhr sein gleich wie Gott etc."16

It is the serpent rather than Eve who here appears as the tale's culprit. The accompanying illustration confirms that the treachery is essentially serpentine by confronting an amicable Adam and Eve on one side of the tree with a malevolently glaring serpent. Moreover, Adam and Eve's position together on the side of the redeemed ${ }^{17}$ delivers the implicit message of their and humanity's eventual redemption, while the apple in Eve's right hand provides yet another piece of evidence for the sixteenth century history of the evolution of the image of Eve's responsibility for introducing evil into the world ${ }^{18}$.

12 Feminists have paid particular attention to these texts, because the Genesis tale of origins has so often been used to justify patriarchal values, most especially in repressive attitudes towards women. See especially Lerner, G.: The Creation of Patriarchy. New York/London 1986; Belanoff, P.: The Fall (?) of the Old English Female Poetic Image. In: Publications of the Modern Language Association 104, 5 (1989) 822-831; Bal, M.: Lethal Love. Feminist Readings of Biblical Love Stories. Bloomington 1987, esp. chapter 5; Aschkenasy, N.: Eve's Journey. Feminine Images in Hebrew Literary Tradition. Philadelphia 1987, esp. 49; Gartner, E.: Eve. The History of an Idea. San Francisco 1985. Others have also noted the history of the text, see Pagels, E.: Adam, Eve, and the Serpent. New York 1988; Alter, R.: The Art of Biblical Narrative. New York 1981, esp. 146; and Röhrich, L.: Adam und Eva. In: Enzyklopädie des Märchens 1. ed. K. Ranke u. a. Berlin/New York 1977, 89-99.

13 Until the 19th century nearly all of the editors and re-writers of Bibles for children were male, with female participation in this genre vanishingly small.

14 See Bottigheimer, R. B.: Lutheranism, Literacy, and Bible Reading in Early Modern Europe. Further Thoughts (forthcoming).

15 Luther indicated in his foreword to the "Passionalbüchlin" that it was intended for both children and simple folk.

16 The single extant copy of the original edition is in the Stadtbibliothek Lindau. The text is reproduced in: Ein bet=buchlin/mit eym Calender und Passional/hưbsch zu gericht. Marti. Luther. Wittembergh. M. D. XXIX. ed. F. Schulz. Kassel 1982.

17 Adam and Eve appear on the left side of the image as it appears on the page; however, an earlier tradition which included God as onlooker, provides us and provided earlier viewers with a knowledge of 'right' and 'left'. The subsequent and dominant tradition placed Eve on the left hand side of the tree according to divine perspective, from which only pirated-and reversed-images such as this one released her.

18 These points were worked out in a slide lecture, "Malum Malum" delivered at the Modern Language Association, Washington DC, 1989, at Clare College, Cambridge, and at the Word and Image Conference, Zürich 1990 as "Eve and the Apple: Left-Right-Wrong”. 
The Lutheran preacher Hartmann Beyer (also Baier, Beier; 1516-77) placed the Fall from Grace in the foreword of his 1555 Historienbibel ${ }^{19}$, stressing that disobedience caused the appearance of the first sin in the world. Numerous illustrations in Beyer's Bible fix both images and symbols of the temptation, the promise of redemption and of the expulsion from the Garden of Eden in the language of Luther's translation of the Bible. Beyer's illustrations provide their own implicit and explicit commentary on the accompanying text. For example, the text for the illustration that directly follows Eve's temptation by the serpent states: "Gott der Herr zürnet mit Adam vmb seins vngehorsams willen, vnd in dem zorn, da er der Schlangen verflucht, tröstet er den Adam und Eva mit der zukunft Christi" ${ }^{20}$, but Beyer alters the following text. He retains the pain in which Eve will bear children, but reformulates the canonical Biblical text as it appears in Luther's translation, so that her desire for her husband ${ }^{21}$ becomes instead a subversion of her will ${ }^{22}$. Luther's relatively-speaking philogynist rendering of Eve evaporated with the disappearance of his Passionalbüchlin, and it was Beyer's harsher text that caught the misogynistic mood of subsequent decades with their view of Eve as seducer and introducer of evil.

Seventeenth century children's Bible production took a new turn in 1669 when Nicolas Fontaine ${ }^{23}$ first published L'Histoire du vieux et du nouveau Testament. Its version of Genesis 3 places Adam at the center of the narrative which is entitled Cheute d'Adam, and its text provides a reasoned interpretation for the serpent's actions: "le demon qui estoit dejá tombé par son orgueil, \& qui ne pouvait souffrir la fidelité des deux innocentes creatures [...] croyant qu'il surmonteroit plus facilement la femme, il s'addressa d'abord à elle" (p. 5) ${ }^{24}$.

In the Germanies, where the production of children's Bibles had been vigorous during the sixteenth century, publication diminished sharply during the seventeenth century. Concurrent with the Thirty Years War which accompanied and caused economic and social dislocations, Bible story collections for children's use bowed to the wisdom literature of Jesus Sirach until the 1670s. At that point, however, fond parents and earnest pastors both returned to the genre and produced numerous, and relatively short-lived works ${ }^{25}$. Their efforts

Reproduced in Reu, J. M.: Quellen zur Geschichte des kirchlichen Unterrichts in der evangelischen Kirche Deutschlands zwischen 1530 und 1600. Teil 1-2. (Gütersloh 1904-35) Reprint Hildesheim 1976, t. 2, 186-288.

20 ibid., 196.

21 The Luther translation of Gen. 3,16 includes "dein Verlangen soll nach deinem Mann sein".

22 "Dein will sol deinem Man vnderworffen sein".

23 Fontaine is frequently listed in card catalogs as the Sieur de Royaumont or incorrectly as Le Maistre de Sacy.

24 The text remains unaltered throughout the 17 th and 18 th centuries. This quotation was taken from a 1712 edition published in Paris at Pierre le Petit.

25 Examples of late 17th century children's Bibles are: Sagittarius, Johann Christfried: Biblische Historien Altes und Neuen Testaments [...]. Altenburg: Gottfried Richter 1670; Lenderich, Bartholomeus: Kleine Historische Biblia [...]. Nürnberg: Johann Hoffmann 1677; Weissmann, M. Ehrenreich: Kinder-Bibel [...]. Stuttgart: Johann Gottfried Zubrodt 1684; and Zeidler, Johann Gottfried: Bilder-Büchlein. Magdeburg: Johann Daniel Müller 1691. For an outline of the subject see Reents, C.: Kinderbibel. In: Theologische Realenzyklopädie 18 (1988) 176-182. 
culminated in the children's Bible bestseller, Johann Hübner's Zweymabl zwey und funffzig Auserlesene Biblische Historien ${ }^{26}$. First published in Leipzig in 1714, it included not only Bible stories, but also catechizing questions ("Deutliche Fragen"), useful precepts ("Nützliche Lehren"), and pious thoughts ("Gottselige Gedanken") in both German and Latin. There was little possibility for misunderstanding the story as Hübner told it: " $7 . \mathrm{Zu}$ dieser Sunde verfúhrte sie [that is, unsere ersten Eltern (RBB)] der Teuffel, 8. welcher sich in eine Schlange verstecket hatte. 9. Diese Schlange sprach zum Weibe: 10 . Ihr werdet mit nichten des Todes sterben, sondern wenn ihr davon essen werdet, so werdet ihr seyn wie GOtt” (p. 9 sq.).

Numbered phrases match numbered questions at the bottom of each page, and the entire text is given canonical authority by marginal notations that identify book, chapter, and verse for each sentence. 'Useful precepts' remind the child-reader of the dangers of disobedience (being driven out of Paradise), the wickedness of lying (the devil's deception), and what one should think upon whenever one enters a garden (the first sin). The 'pious thoughts' appended at the end of Genesis 3 urge the child to think of the Fall from Grace whenever clothes come into view (i. e. constantly), since Adam and Eve hadn't needed them before the Fall.

The handling of guilt in Hübner's Fall from Grace produced an Eve who thought, in good Enlightenment style, that since eating from the Tree of the Knowledge of Good and Evil would make one knowledgeable, intelligent, canny, and clever ('klug'), it must necessarily be good to take the proferred apple, and therefore not only did Eve herself eat, but she also gave some of the fruit to her husband.

The resuscitation of Eve as virtuous reached its zenith in a hymnal of the Reformed Church, where she was apotheosized as a 'tugendvolle Braut' in a prayer of thanksgiving to be said after married sexual relations ${ }^{27}$, a prayer which both incorporates a correspondingly positive attitude toward the physical pleasures of marriage and finds its parallel in the way in which Hübner renders Eve's desire for her husband as something other-and better-than part of God's punishment of all womankind.

A very different Eve was abroad at the same time, the Eve in Johann Peter Miller's (1725-1789) children's Bible with the prepossessing title, Jobann Peter Millers erbauliche Erzäblungen der vornebmsten Geschichten zur Erweckung eines lebendigen Glaubens und der wabren Gottseligkeit ${ }^{28}$. Miller castigated Eve in his Fore-

26 Hübner, J.: Zweymahl zwey und funffzig Auserlesene Biblische Historien Aus dem Alten und Neuen Testamente, Der Jugend zum Besten abgefasset (Leipzig 1714, 1731). Reprint Hildesheim 1986. ed. R. Lachmann/C. Reents. Its history has been described and analysed by C. Reents in: Die Bibel als Schul- und Hausbuch für Kinder. Werkanalyse und Wirkungsgeschichte einer frühen Schul- und Kinderbibel im evangelischen Raum. Johann Hübner, Zweymal zwey und funffzig Auserlesene Biblische Historien [...]. Göttingen 1984.

27 Chur-Pfältzisch Allgemeines Reformirtes Gesangbuch [...]. Frankfurt (Main):Johann Benjamin Andreä 1762.

28 Miller, J. P.: Erbauliche Erzählungen [...]. Helmstädt: Waysenhaus und Weygand in Comm. 1753. 
word, declaring that she was so sinful a creature that she shouldn't appear on its pages, but should yield her place to a good woman, for example, Rebeccah. Publishing history tells the rest of the story. Hübner's Bible stories went through printing after printing, while Miller's enjoyed a far briefer span of published life ${ }^{29}$. More importantly, Hübner's Bible stories can be seen as a point of continuing propagation of Enlightenment values via the schools for decades after his view of Eve had been supplanted by one created by finger-shaking patriarchs in the pulpit.

Not all Bibles offered so ample a narrative as Hübner's. Some seemed to serve rather as mnemonics. The pragmatic English preferred the brevity of The Holy Bible Abridged (1757) ${ }^{30}$. It tells a shorter story in far fewer words: "the subtle serpent, (the Devil) by his artful insinuations, prevailed on the woman to eat of the forbidden fruit" (p.33).

Given the prominence of the serpent in most versions of the Fall from Grace, his absence jolts the unready reader. But disappear he does in bourgeois Zürich of the eighteenth century, when Johann Caspar Lavater presented the material to children in his Cbristliches Handbücblein für Kinder ${ }^{31}$. After God's warning not to eat the forbidden fruit "sie sahen die schöne Frucht so lang an, bis sie sich nicht mehr hinterhalten konnten, davon zu essen, ungeachtet sie GOtt so ernstlich davor gewarnet hatte” (p.22 sq.). The absence of evil, that is, the absence of the serpent, accords well with Lavater's introductory preface to children, which asserts and addresses their immanent goodness. His pedagogical stance is consistent with Enlightenment principles that had been developed in France and had subsequently been incorporated into childrearing manuals in Germany.

In the course of the nineteenth century children's Bibles underwent thoroughgoing transformations. Hübner's venerable texts were altered to introduce the work ethic into the Garden of Eden, and in other children's Bibles the blame for the Fall gradually shifted from the serpent to Eve.

The authors of children's Bibles address a reading public which poses innocent but potentially embarrassing questions about this difficult text. What was it like in Eden? A nineteenth century American children's Bible answered with a description of an agricultural day-laborer's paradise that had "neither

29 I do not mean to assert that Hübner's Bible stories accurately expressed broadly held sentiments about Eve either as an individual or as an archetype. It is far more likely that Hübner's teacher-friendly format made it the school Bible of choice. When, however, Hübner's Eden was completely out of tune with prevailing sentiments in the early 19 th century, it was edited in a thoroughgoing manner and continued to be used in Protestant schools throughout Germany.

30 The Holy Bible Abridged. London: J. Newberry 1757 and frequently thereafter; also much published in America in 18th and early 19 th centuries. In this case the text comes from a late 18th century American edition (Worcester, Mass.: Isaiah Thomas 1786) whose wording is identical.

31 Lavater, J. C.: Christliches Handbūchlein für Kinder. Zürich: David Bürkli 21781. This is above all true in the children's Bibles which Lavater had produced together with Johann Jakob Hess entitled Biblische Erzählungen für die Jugend. They were published and republished in Zürich in the last third of the 18th century. 
blight, mildew nor famine" ${ }^{32}$. A twentieth century children's Bible, on the other hand, offers a fairy tale landscape peopled with magical creatures: "If they were thirsty they needed only to call. Almost immediately two doves would whir down to earth and hold out to them in their little beaks rosecups filled with wine. If they wanted to have a nice ride, they needed only to beckon and two eagles at once came flying down on their great wings. And if they wanted to cross the water, two whales carried them" 33 .

One of the bestselling American children's Bibles of the twentieth century describes Eve as a creature as vain as any wicked stepmother. Its text offers a study in the ludicrous, an echo of fin-de-siècle attitudes towards women as dark and evil creatures of devouring sexuality. Part of the five-page description (which Luther had disposed of in a single sentence) identifies Eve's vanity as the key to humanity's fatal fall, and in so doing, she is remade into a serpent surrogate as part of an elaborately decorative image: "There came an hour in the fullness of morning when Adam was away from the woman, and the serpent, seeing it, approached her and was with Eve alone. She sat in dappled shade from the sun, whose light was on all around them, and whose heat was pleasant to her after the cold of the waters in which she had bathed. There she had seen her own image or reflex in its glass; and she had praised the Lord God at the thought she was so fair. (p. 27) [...] With her long gentle hand she drew back her hair that lay heavy as gold upon her shoulders, and supple as the serpent himself, languished in her own beauty" (p. 31) 34 .

\section{Children's Bibles and the Larger World}

The earliest children's Bibles, that is, those in the sixteenth and seventeenth centuries, faithfully reflect the plots of Old Testament narratives with their excesses of violence and violation. In this sense, children's Bibles parallel the content of popular tale collections in the same period, where brutal violence and frank sexuality form a significant part of the plots of many stories. In children's Bibles we read about Dinah's rape, Lot's incest, and David's lust, the illicit desire of Potiphar's wife, and the gang rape of the Levite's wife. We see in graphic detail the proposed or actual slaughter of children, whether it is Abraham's son, Jephthah's daughter, or all Jewish boys. Women murder men, and men turn their knives against women in scenes as bloody as those in nineteenth century penny dreadfuls.

In and of itself the extreme variability evident in retellings of Genesis 3 during the five centuries of printed children's Bibles only confirms what folk narrativists know of the variability of folkloristic genres in general ${ }^{35}$. However, the variabil-

32 The Fall of Adam. Philadelphia: B. \& J. Johnson 1800.

33 Asch, S.: In the Beginning. Stories from the Bible. Ill. E. Klemm. New York: Schocken 1966.

34 Mare, W. de la: Stories from the Bible. Ill. E. Ardizzone. (New York, Toronto and London 1929) New York: Knopf 1967.

35 See the essays in Görög-Karady, V. (ed.): D'un conte ... à l'autre. La variabilité dans la littérature orale. Paris 1990. 
ity in retellings of Genesis 3 points toward thoroughgoing shifts of both perspective and emphasis within children's Bibles as a whole, so that we may regard each children's Bible as a vehicle for reflecting and transmitting a particular and identifiable set of social and moral ethics, while the publishing history of each of these volumes helps explain the extent to which each found acceptance. The few, and brief, excerpts above show changing views of the Fall from Grace as a whole and of who was responsible for it in individual terms. Other characteristics emerge from children's Bibles when they are read one after the other. Sexuality, for example, begins to disappear around the middle of the eighteenth century, a hundred years before the emergence of what we have come to think of as 'Victorian' morality. On the other hand, the adumbration of work, long trumpeted as a quintessentially Protestant characteristic, only emerges in late eighteenth century children's Bibles. Gratitude, which looms so large in later nineteenth century fiction for children on both sides of the Atlantic, also makes its first appearance as a virtue which is stressed and rewarded in the late eighteenth century.

Alterations in several categories-wording, illustrations, and internal commentary-provide analytic access points for assessing changes in attitudes which themselves mirror shifts in contemporaneous social values. Although country, confession, century, and class correlate with the content of children's Bibles, each of these categories is subject to supervening currents. In terms of interconfessional similarities, for example, there is a striking similarity in the portrayal of the Fall from Grace between eighteenth century Protestant children's Bibles from Zürich and school Bibles produced in early nineteenth century Catholic Bavaria. Both incorporate Enlightenment ideas, and both express a seventeenth century Miltonian view of the Fall from Grace.

One finds equally notable in $\mathrm{r}$ a confessional dis similarities. For example, two Catholic children's Bibles, both published in the United States in the 1950s (1952 and 1955) and both with archepiscopal imprimatur differ radically from one another. The first offers its young readers a serpentine Lucifer, who says "God is afraid to have you know good from evil. Try the fruit. It is good. [...] Eve eats. Adam eats. [...] They disobeyed" 36 . The other one castigates the female: "Women, we are told, are prone to curiosity. Once the serpent had spoken, Eve could not restrain hers" 37 .

The differences between these two children's Bibles is not confessional-both are Catholic and both were approved for Catholic reading by the highest episcopal authority. Other reasons would seem to outweigh confessional origins as the cause of such differing views of the events in Genesis 3 . The first one comes

36 God's Story Book. A First Book of Bible Stories for Little Catholics. Ill. L. Ward. St Paul, Minn.: Catechetical Guild 1952, n. p. (Kerlan Collection, University of Minnesota Library).

37 Rops, D.: The Book of Books. The Story of the Old Testament. Trans. D. O'Kelly. New York: P. J. Kennedy \& Sons 1955, 30 (Reformed Theological Seminary Library, New Brunswick, not accessioned). 
from the American Midwest, St Paul Minnesota, the heartland of populist sentiment, where Swedes and Norwegians had brought with them to the New World a centuries-long tradition of more equal rights for women than was the case elsewhere in Europe. The other was published in northeastern New Jersey, home to immigrants from southern Europe, where historically very different traditions regarding women had obtained.

A more prominent distinction separates Christian from Jewish children's Bibles. As a group children's Bibles written by and for Christians accept a sin-based interpretation of Genesis 3. In marked contrast to this version of Original Sin, twentieth century Jewish children's Bibles sometimes entirely omit Genesis 3, or else gloss over the inculpating mood of Christian versions. A typical narrative for Jewish children reads: "In the beginning God created heaven and earth. He made Adam, the first man, and Eve, the first woman. In the lovely Garden of Eden, they enjoyed the beautiful trees and ate their delicious fruits"38.

Not only does the picture accompanying this text show Ad a m reaching for fruit in a tree (p. 6), the text also avoids associating knowledge with sin or transgression. From the phrase, "[they] ate their delicious fruits", the little book proceeds directly to Cain and Abel. No serpent, no curse, no angel with a flaming sword, no worry about whether Adam and Eve will eat from the Tree of Life or what the accursed consequences of that act might be. Talmudic but not Midrashic tradition is manifested in these values. This fact suggests the primacy of contemporary values over historic tradition in the re-creation of Biblical text for children, for earlier fictional texts embody misogynistic Midrashic values ${ }^{39}$.

\section{Illustrations and Children's Bibles}

In general children's Bibles were well illustrated from the moment of their Protestant inception with Luther's Passionalbüchlin. That may not seem remarkable, but in publishing history terms, it represents part of a distinctive phenomenon: the disproportionate illustration of printed religious material. For example, in sixteenth century France, only $20 \%$ of all books published were illustrated; in the seventeenth century, the proportion was even smaller, about $10-15 \%$. Yet in both centuries, $5 / 6$ of all illustrated books were religious books. Illustrations were an integral and essential part of religious literature printed for the laity ${ }^{40}$. This single fact requires us to consider illustration and text together in children's Bibles. Aschkenasy, N.: Dinah and the Midrash. Address delivered at the Modern Language Association, Washington DC, 1989; see also ead. (above, not. 12).

40 See Pastoureau, M.: Lillustration du livre. Comprendre ou rêver. In: Martin/Chartier (above, not. 5) 500-529. 
Dealing with the illustrations themselves requires a radically different iconographic approach from that of an Erwin Panofsky or of an Ernst Gombrich ${ }^{41}$. It is not polysemic ambiguity which is in question in religious illustrations, but the affirmation of a particular interpretation of an inherently polysemic text. To take Genesis 3 once again as an example, we see that the way in which it outlines temptation and its consequences is inherently ambiguous. Does Eve's temptation represent a bad trick played on humanity by an omniscient but capricious god? Does the temptation precipitate a fall which was peculiarly man's, that is, Adam's? Is the Fall itself evidence of the Pandora-like weakness that lies hidden in Everywoman, that is, Eve? Was the Fall an inescapable sin that Adam and Eve together were incapable of preventing? Illustrations form an important partnership with the text and provide a form of internal exegesis for children's Bibles, playing a central role in the resolution of these and similar puzzles.

Illustrations in children's Bibles can also be highly problematic. Generally accepted unquestioningly as a standard adjunct for books for young readers, they must be queried carefully. Which moment of a given story has an artist illustrated, and how has it been rendered? Illustrations for the Fall from Grace dominate most children's Bibles. It is in many cases the only illustration. Small wonder, since profound and enduringly important relationships are established in these opening chapters of the canonical Bible. But wh at these relationships consist of and which way the balance tips shows up in two places, in the text and in the accompanying illustrations. I do not believe that it was accidental that some of the earliest Protestant illustrations of the temptation show Adam offering the apple to Eve. Or that the next generation of illustrations depicts Adam and Eve together accepting the apple. Or that subsequent iconography settles into the long-familiar pattern of Eve offering the apple to Adam. These shifts can be charted from the changing images on the pages of Luther's Passionalbuichlin, Hartmann Beyer's Historienbibel, and the images by Matthäus Merian in Nicolas Fontaine's Histoire du vieux et du nouveau Testament, to mention only a few.

The illustration of the Fall from Grace is only one of many which pose questions of enduring importance. For instance, what events in the Bible may be displayed? Until the early eighteenth century the lust of Potiphar's wife is made abundantly clear by showing her bare-breasted and eagerly clutching at Joseph's coat. But in the later eighteenth century her clearly delineated desire slowly fades from the page as illustrators depict a slightly later moment in the tale, when-her breasts covered with a bedsheet-she accuses Joseph of attempted rape. In the nineteenth century she herself ultimately disappears from both word and image in many children's Bibles.

Unmerited violence is another.subject that changes over time. Early children's Bibles include the gang rape of the Levite's wife, and his butchering her body into twelve pieces which he then sent to the twelve tribes of Israel to incite

41 See, for example, Panofsky, E.: Meaning in the Visual Arts. (Garden City, N.Y. 1955) Reprint Woodstock, N.Y. 1974; id.: Studies in Iconology. New York/Oxford 1939; Gombrich, E.: Art and Illusion. Princeton 1961. 
them to revenge. The woman herself is depicted variously being set upon by rapists, or lying dead or dying after the attack. This violence also fades away in the course of the eighteenth century, but the power of fathers or rulers to slaughter the innocent does not. Abraham's willingness to sacrifice Isaac, a horrifying tale, remains and even grows in importance, as does the massacre of innocents in both the Old and New Testaments.

Translation also plays a role; and like all translations, those of children's Bibles represent cultural reformulations. Johann Hübner's little Zweymabl zwey und funffig Biblische Historien has been translated into languages as diverse as Russian, Basque, Hungarian and Romansch, as well as into English, French, and Dutch. With each translation, changes crept into the prose and into the little summations that follow each chapter, changes that reveal identifiable beliefs and differing priorities. It is no accident that God is characterized as 'divine' in English, but 'plein d'Intelligence' (p.2) in French in a French-English dual language edition ${ }^{42}$. So crass an example is meant only to point up translations of children's Bibles as another means of defining changes in social attitudes which occur at linguistic and cultural boundaries.

Within a study of children's Bibles, the immediate object of study is a published book, one which somehow managed to survive for decades or for centuries among others that have been lost. Such a book is a physical object which has a distinctive appearance and size and which at one time had a particular price. Beyond the artifact, book, there once existed legions of longgone people, who conceived of the book, who wrote the directions for its use, and who begged, borrowed, or stole the illustrations which grace its pages; who bought the paper and designed the typeface; who printed it, bound it (cheaply or expensively); and who loaded the unfinished product into wicker baskets or the finished product onto wooden wagons. Unlike many other kinds of books, children's Bibles are an intensely local phenomenon. They rarely travelled far from the printshop where they were produced. For several centuries, children's Bibles printed in Leizpig were sold near Leipzig; if the same book was sold in Zürich, then it had in all likelihood been printed from plates made up in Zürich, not from the ones used to produce it in Leipzig. One also watches with fascination as the same book appears first in Boston, then in Worcester, New York, and Philadelphia, working its way down the East Coast of America, changing its typeface, coarsening its illustrations, but only occasionally altering its language. This expresses, of course, the state of printing technology until the nineteenth century. A book's changing appearance in its many published incarnations has implications for the study of early children's Bibles ${ }^{43}$, for since they are rarely found far from where they first appeared, we may infer national and international distribution patterns different from elite published works.

42 Hübner, J.: Youth's Scripture Kalendar: or, Select sacred stories for every Sunday throughout the Year [...]. Calculated for the use of schools. London: T. Caslon 1759.

43 This is also true for publishing ephemera like almanacs. 
The reader whom we imagine to have held the book in his or her small hand is the ultimate subject of this study. What might the child have thought about this particular book? The length of the tales told, their simplicity or complexity, the kind of language in which they are told, signs of their use such as scribbled marginal comments or painfully traced Abc's-each of these offers clues to the place the book had in the life of its young owner, just as its changing contents tell us what one generation after another found acceptable for its children.

\section{Bibliographical Note}

The general absence of secondary literature in my footnotes reflects the paucity of studies of children's Bibles themselves. Christine Reents' study of Johann Hübner (Die Bibel als Schul-und Hausbuch für Kinder. Göttingen 1984), Richard Gassen's study of Wendelin Rihel's 1540 Bible for the laity (Die Leien Bibel des Straßburger Druckers Wendelin Ribel. Kunst, Religion, Pädagogik und Buchdruck in der Reformation. In: Memminger Geschichtsblätter 1983/ 84, 1-278) and Reinhard Wunderlich's Johann Peter Hebels "Biblische Geschichten" (Göttingen 1990) are the principal monographs available. Regine Schindler offers a brief overview in Die Bibel für Kinder-einst und jetzt (Zürich 1982). Studies of Luther's translations of the Bible ignore his own children's Bible. Luther's Passionalbücblin has not yet been investigated by historians, although it has to date been reprinted twice in the 20th century, most recently as Martin Luther. Ein Betbüchlein. 1529 (Kassel 1982), with a brief afterword by Frieder Schulz. Excellent articles on individual children's Bibles appear in volume 1 of the Handbuch zur Kinder- und Jugendliteratur. (ed. T. Brüggemann/O. Brunken. Stuttgart 1986) and volume 3 (ed. T. Brüggemann/H.-H. Ewers. Stuttgart 1982). Several studies address thumb Bibles or hieroglyphic Bibles, but these tiny publications are rarely children's Bibles.

A few articles address single Bibles or the history of individual stories (Brecht, M.: Christian Gottlob Barths "Zweimal-zweiundfünfzig biblische Geschichten"-ein weltweiter Bestseller unter den Schulbüchern der Erweckungsbewegung. In: Schindler, A. et al. [edd.]: Hoffnung der Kirche und Erneuerung der Welt. Göttingen 1985; Kittsteiner, H. D.: From Grace to Virtue: Concerning a Change in the Presentation of the Parable of the Prodigal Son in the 18th and Early 19th Centuries. In: Social Sciences Information 23 [1984] 955-975; Mayer, T.: Biblische Geschichten im evangelischen Religionsunterricht in Baden. In: Erbacher, H. [ed.]: Vereinigte Evangelische Landeskirche in Baden 1821-1971. Karlsruhe 1971, 392-477; Reents, C.: Kinderbibel. In: Theologische Realenzyklopädie 18 [1988] 176-182). Religious education teachers and book reviewers occasionally contribute $2-3$ page musings on the subject, sometimes expressing disapproval, but more often surprise.

The general subject of children and religion has been studied from many points of view. Children's religious services have been well documented, and the bibliography of catechetical literature is immense. Children's Bibles themselves have been noted within confessional pedagogical literature (see, for example, Niemeyer, A. H.: Briefe an christliche Religionslebrer. Halle 1797); within studies of literacy (Strauss, G.: Luther's House of Learning. Baltimore etc. 1978; id.: Lutheranism and Literacy. In: Religion and Society in Early Modern Europe 1500-1800. ed. K. von Greyerz. London 1984,109-123); as an object of pedagogical interest (Zurhellen-Pfleiderer, E./Zurhellen, O.: Wie erzäblen wir den Kindern die biblischen Gescbicbten? Tübingen 1906); and as a component of children's literature (Lehtonen, U.: Lastenkirjallisuus suomessa 1543-1850 [Children's literature in Finland 1543-1850]. Tampere 1981; Klingberg, G.: Svensk barn-och ungdomslitteratur 1591-1839. En pedagogikbistorisk och bibliografisk översikt. Stockholm 1964 [English summary: p. 341-359]; Wegehaupt, H.: Vorstufen und Vorläufer der deutschen Kinder-und Jugendliteratur bis in die Mitte des 18. Jabrbunderts. Berlin 1977). In studies where one might have expected to find analyses of 
children's Bibles, they have not been included, for example in popular culture (Vogel, P. H.: Europäische Bibeldrucke des 15. und 16. Jabrbunderts in den Volkssprachen. Baden-Baden 1962); in the history of literate culture (Grenzmann, L./Stackmann, K. [edd.]: Literatur und Laienbildung im Spätmittelalter. Stuttgart 1984); private life (Ariès, P. et al. [edd.]: Histoire de la vie privée 1-5. Paris 1985-87); or of popular religion (Russell, P. A.: Lay Theology in the Reformation. Cambridge 1986).

The remarkable absence of children's Bibles from scholarly literature probably stems from two causes. Historically, children's Bibles have seemed to represent a non-fact, because there has been a great disparity between both the content and the presentation of Bible stories for children's use on the one hand and scholarly understanding and treatment of the same material on the other. Only in the 20th century has there been an attempt to bridge the gulf between the two areas. Personally, nearly every adult writer of memoires who refers to the place of children's Bibles and Bible stories in their schooling does so with revulsion. Teachers of religion reflect this when they refer to the lamentable state of religious education and its equally lamentable results. Together these two sources of scholarly discomfiture conspired to divert the gaze of scholars for generations, but that situation is now changing. 